Bangladesh J. Bot. 44(1): 79-84, 2015 (March)

\title{
EFFECTS OF PLANT GROWTH REGULATORS ON LENTIL (LENS CULINARIS MEDIK.) CULTIVARS
}

\author{
Fethi Ahmet Ozdemir, Musa Turker ${ }^{1}$ and Khalid Mahmood Khawar ${ }^{2}$ \\ Department of Molecular Biology and Genetics, Faculty of Sciences, \\ Bartin University, Bartin, 74110, Turkey
}

Key words: Effect, Plant growth regulators, Lentil, Explant, Cultivars

\begin{abstract}
Lentil (Lens culinaris Medik.) is an annual pulse legume crop of immense economic importance. This study reports use of 16 lentil cultivars' shoot tips, internode, hypocotyl, cotyledon and root explants cultured on MS medium containing $3 \mathrm{mg} / 1 \mathrm{BAP}-0.5 \mathrm{mg} / 12,4-\mathrm{D}$ or $0.25 \mathrm{mg} / 1 \mathrm{IBA}$ for shoot regeneration. The results showed maximum shoot regeneration from cv. Yesil 21 on internode explants on 3mg/1 BAP-0.5 mg/1 2,4-D. Best shoot regeneration on MS medium containing $0.25 \mathrm{mg} / \mathrm{l}$ IBA was noted on internode explants of cv. Seyran 96. In general shoot regeneration on $0.25 \mathrm{mg} / \mathrm{l}$ IBA was better compared to $3 \mathrm{mg} / \mathrm{l}$ BAP and $0.5 \mathrm{mg} / 1$ 2,4-D. Well developed shoots from all cultivars regenerated on both types of culture media were rooted on MS medium containing $0.19 \mathrm{mg} / 1 \mathrm{NAA}$. A system to regenerate lentil is established that will help in easy genetic transformation in future.
\end{abstract}

\section{Introduction}

Lentil (Lens culinaris Medik), with its high carbohydrate, protein and amino acid contents is included among 30 most important economically important plant groups that are used as main source of nutrition to many people (Malik and Saxena 1992a,b, Fratini and Ruiz 2002, Khawar and Ozcan 2002).

Previous research-starting from Bajaj and Dhanju (1979) followed by Williams et al. (1986), Saxena and King (1987), Mallick and Rashid (1989), Malik and Saxena (1992a, b), Ahmad et al. (1997), Polanco (2001), Polanco et al. (1988), Polanco and Ruiz (1997), Ye et al. (2000, 2002), Khawar and Özcan (2002), Khawar et al. (2004), Fratini and Ruiz (2002), Sevimay et al. (2005), Aasim et al. (2012) agree that the lentil is a recalacitrant plant, that is difficult to root. The researchers have adapted different methods to root the plant which are tedious and difficult to regenerate.

Therefore, the present study aimed at developing a protocol for rooting of in vitro grown shoots using a large variety of lentil germplasm that should be simple and repeatable to help in future transgenic and breeding studies.

\section{Material and Methods}

The plant material consisted of 16 commercially important lentil cultivars, namely Sazak 91, Sultan I, Kayi 91, Pul 11, Yesil 21, Meyveci 2001, Firat 87, Özbek, Ciftci, Erzurum 89, Malazgirt 89, Seyran 96, Kirmizi 51, Yerli kirmizi, Kafkas and Emre 20. The seeds were obtained from the Department of Field Crops, Yuzuncu Yil University. The study was carried out at the Department of Biology of said University. Surface sterilization of the lentil seeds was done with $100 \%$ commercial bleach (ACE-Turkey, $5 \% \mathrm{NaOCl}$ ) for 20 min. Following the sterilization, the seeds

*Author for correspondence: <kmkhawar@gmail.com $>{ }^{1}$ Department of Biology, Faculty of Sciences, Yuzuncu Yil University, 65100, Van, Turkey. ${ }^{1}$ Department of Field Crops, Faculty of Agriculture, Ankara University, 06110, Ankara, Turkey. 
were rinsed in double distilled sterilized water for $3 \times 5 \mathrm{~min}$. These seeds were then cultured on MS solidified with $0.8 \%$ agar (Sigma type A) and $30 \mathrm{~g} / 1$ sucrose in Erlenmeyer flask at $24 \pm 2^{\circ} \mathrm{C}$ for germination. Double distilled sterilized water was used for the preparation of the MS medium. The $\mathrm{pH}$ of the medium was adjusted to 5.8. The medium was autoclaved at 1.5 atmospheric pressure at $121^{\circ} \mathrm{C}$ for $20 \mathrm{~min}$. Seed germination was carried out under 16 light photoperiod at temperature of $24 \pm 2^{\circ} \mathrm{C}$ having $50 \mu \mathrm{mol} / \mathrm{m} 2 / \mathrm{sec}$ light provided by fluorescent lights in growth chamber.

Shoot tips, internode, hypocotyl, cotyledon and root explants were excised aseptically from the growing seedlings of 16 cultivars on MS medium and cultured on MS medium containing 3 $\mathrm{mg} / \mathrm{l} \mathrm{BAP}-0.5 \mathrm{mg} / 1$ 2,4-D or $0.25 \mathrm{mg} / \mathrm{l} \mathrm{IBA}$ regeneration medium. All cultures were maintained at $24 \pm 2^{\circ} \mathrm{C}$ under 16 light photoperiod $\left(50 \mu \mathrm{molm}^{-2} \mathrm{sec}^{-1}\right)$ light provided by fluorescent lights in growth chamber.

All treatments of regeneration or rooting experiments had three replicates containing 5 explants each. The means for data for frequency of shoot regeneration, mean number of shoots per explant were compared using one way ANOVA to determine standard error with the help of statistical software SPSS 16.00 for windows. If the explants callused they were not subjected to ANOVA. The post hoc tests were performed using Tukey's test. All data taken in percentage were subjected to arcsine transformation as described by Snedecor and Cochran (1967) before statistical analysis.

\section{Results and Discussion}

The number of shoots per explant on all explants after 12 weeks of culture and standard errors values are given in Table 1. The number of shoots per explant ranged $0.6 \pm 0.47$ to $8.1 \pm$ 2.44. Maximum number of shoots per explant were recorded on cv. Yeşil 21 and minimum number of shoots were recorded on cv. Erzurum 89. Out of 16 cultivars 6 namely - Firat 87, Özbek, Erzurum 89, Malazgirt 89, Yerli Kirmizi, and Emre 20 had poor regeneration with less than 2 shoots per explant. Internode and cotyledon explants from cv. Pul 11, Meyveci 2001, Firat 87, Ciftici, Seyran 96 and Kafkas developed callus without any shoot regeneration. Maximum number of shoots per internodal explant were recorded on cv. Yesil 21. In cotyledonary explant maximum number of shoots were recorded on cv. Erzurum 89. Cotyledon explant of 12 cultivars induced callus without any shoot regeneration. Minimum and maximum number of $0.3 \pm 0.47$ and $3.3 \pm 0.81$ shoots per explant were induced on cv. Sultan 1 and Erzurum 89, respectively. No shoot regeneration was recorded on root explant from any cultivar. However, the calli ranged in size and diameter on each of the 16 cultivars (data not shown).

An overview of the above results shows that the shoot regeneration is clearly affected by the type of explants and the cultivar. Maximum shoot regeneration was noted on shoot tip explants followed by regeneration on hypocotyl and internodes. Cotyledon explant showed minimum shoot regeneration on minimum number of cultivars.

The number of shoots per explant on all explants after 12 weeks of culture and standard error values are given in Table 2 .

The results showed variable number of shoots per shoot tip explant on MS medium containing $0.25 \mathrm{mg} / \mathrm{l} \mathrm{IBA}$. No callusing was recorded on any explant. The number of shoots per explant ranged $7.5 \pm 3.60$ to $23.1 \pm 3.60$.. Maximum number of shoots per explant were recorded on cv. Kafkas. Minimum number of shoots was recorded on cv. Sultan 1.

Internode explant induced shoot regeneration in range of $3.1 \pm 4.35$ to $25.5 \pm 2.64$. Maximum number of shoots per explant was recorded on cv. Seyran 96. Less than 8 shoots were recorded on cv Yesil 21, Meyveci 2001, Özbek, Erzurum 89 and Malazgirt 89. 
Hypocotyl explant had shoot regeneration in range of $5.3 \pm 3.46$ to $21.2 \pm 3.60$. Maximum number of shoots per explant were recorded on cv. Kayi 91. Less than 10 shoots per explant were recoded on cv. Sultan1, Pul 11, Yesil 21, Ozbek, Ciftci, Erzurum 89, Kirmizi 51 and Emre 20. Cotyledon explant had shoot regeneration in range of $3.1 \pm 1$ to $13.1 \pm 2.64$ shoots per explant. Maximum number of shoots per explant was recorded on cv. Ciftci. More than or equal to 9 shoots per explant were recoded on cv. Kayi 91, Firat 87, Ozbek, Ciftci and Sazak 91. No shoot regeneration was recorded on root explants of any cultivar.

Table 1. Effects of $3.0 \mathrm{mg} / \mathrm{l} \mathrm{BAP}$ and $0.5 \mathrm{mg} / \mathrm{l}$ 2,4-D on induction of shoots from different explants of 16 lentil cultivars.

\begin{tabular}{lllll}
\hline \multicolumn{1}{c}{ Cultivar } & \multicolumn{5}{c}{$3.0 \mathrm{mg} / \mathrm{l} \mathrm{BAP}+0.5 \mathrm{mg} / \mathrm{l} \mathrm{2,4-D}$} \\
\cline { 2 - 5 } & Shoot tip & Internode & Hypocotyl & Cotyledon \\
\hline Ciftci & $6.1 \pm 1.3 \mathrm{~b}$ & Callus & $2.1 \pm 0 \mathrm{~b}$ & Callus \\
Emre 20 & $1.1 \pm 0.1 \mathrm{~d}$ & $1.4 \pm 1 \mathrm{c}$ & $1.6 \pm 1.15 \mathrm{c}$ & $1.6 \pm 1.52 \mathrm{c}$ \\
Erzurum 89 & $0.6 \pm 0.47 \mathrm{~d}$ & $1.0 \pm 0.81 \mathrm{c}$ & $3.1 \pm 1.63 \mathrm{~b}$ & $3.3 \pm 0.81 \mathrm{a}$ \\
Firat 87 & $2.0 \pm 1.41 \mathrm{~d}$ & Callus & $2.2 \pm 0 \mathrm{c}$ & Callus \\
Kafkas & $2.2 \pm 1.73 \mathrm{~d}$ & Callus & Callus & $"$ \\
Kayi 91 & $2.3 \pm 0.47 \mathrm{~d}$ & $5.9 \pm 0.81 \mathrm{~b}$ & $2.3 \pm 0 \mathrm{c}$ & $"$ \\
Kirmizi 51 & $2.3 \pm 1.73 \mathrm{~d}$ & $0.6 \pm 1.15 \mathrm{c}$ & $0.3 \pm 0.57 \mathrm{c}$ & $"$ \\
Malazgirt 89 & $1.2 \pm 0.81 \mathrm{~d}$ & $2.4 \pm 0.81 \mathrm{c}$ & $1.3 \pm 0.47 \mathrm{c}$ & $"$ \\
Meyveci 2001 & $2.2 \pm 0.81 \mathrm{~d}$ & Callus & $1.3 \pm 0 \mathrm{c}$ & $"$ \\
Özbek & $1.1 \pm 0.81 \mathrm{~d}$ & $1.6 \pm 1.24 \mathrm{c}$ & Callus & $"$ \\
Pul 11 & $5.0 \pm 1.41 \mathrm{bc}$ & Callus & $6.3 \pm 1.24 \mathrm{a}$ & $"$ \\
Sazak 91 & $3.3 \pm 1.15 \mathrm{c}$ & $4.5 \pm 2.64 \mathrm{~b}$ & $1.3 \pm 0.57 \mathrm{c}$ & $"$ \\
Seyran 96 & $2.4 \pm 0.81 \mathrm{~d}$ & Callus & Callus & $"$ \\
Sultan1 & $5.3 \pm 1.52 \mathrm{bc}$ & $1.6 \pm 0.57 \mathrm{c}$ & $2.1 \pm 0 \mathrm{c}$ & $0.3 \pm 0.47 \mathrm{~b}$ \\
Yerli Kirmizi & $1.1 \pm 1 \mathrm{~d}$ & $0.6 \pm 1.15 \mathrm{c}$ & $1.3 \pm 0.57 \mathrm{c}$ & $2.1 \pm 0.57 \mathrm{~b}$ \\
Yesil 21 & $8.1 \pm 2.44 \mathrm{a}$ & $11.6 \pm 0.94 \mathrm{a}$ & $3.1 \pm 2.05 \mathrm{~b}$ & Callus \\
\hline
\end{tabular}

All values in a vertical column shown by different small letters are statistically different at $\mathrm{p}<0.05$ using

Tukey's t test. $\pm=$ standard error.

A comparison of the results showed that cultivars and explants were statistically affected differently $(\mathrm{p}<0.001)$ by the $0.25 \mathrm{mg} / \mathrm{IBA}$ in terms of shoot regeneration. When the explants were compared, it was found that the maximum number of shoots per explant were induced on shoot tip followed by hypocotyl, internode and cotyledon explants.

Rooting of 16 lentil cultivars that showed shoot regeneration was achieved on MS medium containing $0.19 \mathrm{mg} / 1$ NAA. In vitro regenerated roots were hard, fragile and thick. No mortality was recorded on any rooted shoot; all of which were induced on lowest internode and adventitous in nature.

All plants could be acclimatized without any problem. They set seeds under greenhouse conditions.

A set of three selected plants from each of the acclimatized cultivars was examined for their roots after 60 days of culture by taking them out of pots to note their rooting behavior. All in vitro regenerated roots had decayed and were replaced by new roots that were branched and longer. 
The present study presents an efficient, easy and reliable protocol for shoot regeneration and rooting of difficult to root leguminous plant named lentil. This study is of importance as the plant is recalcitrant and the previous reports emphasize the need to simplify the regeneration protocol for easy transformation. It is believed that the results of this study will help in setting guideline for future research in relation to lentils.

Table 2. Effects of $0.25 \mathrm{mg} / \mathrm{l}$ IBA on induction of shoots from different explants of 16 lentil cultivars.

\begin{tabular}{lllll}
\hline Cultivar & \multicolumn{4}{c}{$0.25 \mathrm{mg} / \mathrm{IBA}$} \\
\cline { 2 - 5 } & Shoot tip explant & Internode & Hypocotyl & Cotyledon \\
\hline Ciftci & $14.1 \pm 5.56 \mathrm{~d}$ & $8.2 \pm 1 \mathrm{~d}$ & $9.5 \pm 3.60 \mathrm{~d}$ & $13.1 \pm 2.64 \mathrm{a}$ \\
Emre 20 & $14.1 \pm 6.08 \mathrm{~d}$ & $10.5 \pm 2.46 \mathrm{c}$ & $5.3 \pm 3.46 \mathrm{f}$ & $5.2 \pm 6.08 \mathrm{~g}$ \\
Erzurum 89 & $18.1 \pm 4.35 \mathrm{c}$ & $5.1 \pm 2.64 \mathrm{~d}$ & $7.1 \pm 3.60 \mathrm{e}$ & $3.1 \pm 1 \mathrm{i}$ \\
Firat 87 & $15.2 \pm 1.73 \mathrm{~d}$ & $8.6 \pm 3.46 \mathrm{~d}$ & $18.3 \pm 3.60 \mathrm{~b}$ & $9.0 \pm 2.64 \mathrm{c}$ \\
Kafkas & $23.1 \pm 3.60 \mathrm{a}$ & $10.1 \pm 6.08 \mathrm{c}$ & $13.4 \pm 0 \mathrm{c}$ & $6.4 \pm 1 \mathrm{f}$ \\
Kayi 91 & $14.1 \pm 3.60 \mathrm{~d}$ & $11.2 \pm 4.35 \mathrm{c}$ & $21.2 \pm 3.60 \mathrm{a}$ & $11.1 \pm 2.64 \mathrm{~b}$ \\
Kirmizi 51 & $10.1 \pm 2.64 \mathrm{e}$ & $22.1 \pm 4.58 \mathrm{a}$ & $9.5 \pm 6.24 \mathrm{~d}$ & $7.1 \pm 3.60 \mathrm{e}$ \\
Malazgirt 89 & $21.1 \pm 1.73 \mathrm{~b}$ & $5.3 \pm 1.73 \mathrm{~d}$ & $11.2 \pm 4.35 \mathrm{~d}$ & $8.2 \pm 2 \mathrm{~d}$ \\
Meyveci 2001 & $21.1 \pm 3.60 \mathrm{~b}$ & $5.5 \pm 1 \mathrm{e}$ & $13.2 \pm 2.64 \mathrm{c}$ & $7.1 \pm 1.73 \mathrm{e}$ \\
Özbek & $17.1 \pm 2.64 \mathrm{c}$ & $3.1 \pm 4.35 \mathrm{e}$ & $9.6 \pm 2.64 \mathrm{~d}$ & $11.1 \pm 5.29 \mathrm{~b}$ \\
Pul 11 & $22.4 \pm 4.58 \mathrm{~b}$ & $14.4 \pm 3.60 \mathrm{~b}$ & $9.1 \pm 2.64 \mathrm{~d}$ & $7.2 \pm 1.73 \mathrm{e}$ \\
Sazak 91 & $10.2 \pm 1.73 \mathrm{e}$ & $16.3 \pm 0 \mathrm{~b}$ & $18.2 \pm 2.64 \mathrm{~b}$ & $9.3 \pm 2.64 \mathrm{a}$ \\
Seyran 96 & $17.2 \pm 4.35 \mathrm{c}$ & $25.5 \pm 2.64 \mathrm{a}$ & $14.2 \pm 3.60 \mathrm{c}$ & $4.3 \pm 1 \mathrm{~h}$ \\
Sultan1 & $7.5 \pm 3.60$ & $11.1 \pm 1.52 \mathrm{c}$ & $8.1 \pm 2.64 \mathrm{e}$ & $5.1 \pm 1.73 \mathrm{~g}$ \\
Yerli Kirmizi & $13.1 \pm 4.35 \mathrm{~d}$ & $13.3 \pm 3.60 \mathrm{~b}$ & $11.10 \pm 2 \mathrm{~d}$ & $8.5 \pm 4.58 \mathrm{~d}$ \\
Yesil 21 & $16.3 \pm 3.46 \mathrm{c}$ & $7.3 \pm 4.58 \mathrm{~d}$ & $10.0 \pm 2.64 \mathrm{~d}$ & $6.2 \pm 4.35 \mathrm{f}$ \\
\hline
\end{tabular}

All values in a vertical column shown by different small letters are statistically different at $\mathrm{p}<0.05$ using Tukey's t test. $\pm=$ standard error.

When the shoot regeneration on MS medium containing $3 \mathrm{mg} / \mathrm{l} \mathrm{BAP}+0.5 \mathrm{mg} / \mathrm{l} 2,4-\mathrm{D}$ or 0.25 $\mathrm{mg} / \mathrm{l} \mathrm{IBA}$ is compared, $0.25 \mathrm{mg} / \mathrm{l}$ IBA seems to be favorable for shoot regeneration. Previous studies by Ghanem (1989) is not in line with these results.

Selection of a suitable explant at correct developmental stage plays a key role in successful establishment of culture under in vitro conditions. Morphological integrity of an explant along with the proper choice of plant growth regulators strongly influence induction of optimal callus and shoot regeneration (Khawar et al. 2005). The multiple shoot induction rate and morphogenetic response significantly varied to a greater extent according to the explant type and plant growth regulators concentrations (Özgen et al. 1998). Type of explant and culture medium with specific growth regulator concentrations influenced the organogenesis in the present study is in agreement with Basalma et al. (2008). It seemed as if the competence of regeneration was strongly related to the type of the explant and growth regulator used in the study is in agreement with McDaniel (1984) and Christianson and Warnick (1985). Lack of development of competent meristems lead to poor regeneration or development of callus.

While expecting rooting, a booming in offshoots was observed on MS medium containing $0.19 \mathrm{mg} / \mathrm{l} \mathrm{IBA}$. Previous reports does not support that the lentil shoot regeneration could be obtained on MS medium containing any concentration of IBA. IBA has been used to root the lentil by Khawar et al. (2004). The researchers found that the IBA is helpful in rooting of only $25 \%$ 
material. Rest of the materials induced callus at the base of shoots which hindered rooting of the explants. However, Aasim et al. $(2008,2009,2012)$ has reported that IBA could promote shoot regeneration in the rooting medium on cowpea cv. Akkız; which is another leguminous plant. The results further, emphasize that IBA could be an effective growth regulator for lentil micropropagation; as the shoots that were obtained from this medium to root were more prone to rooting compared to the shoots that were regenerated on MS medium containing BAP-2,4-D. The results of Khawar et al. (2004), who induced shoots using thidiazuron, a synthetic cytokinine and rooted them in IBA medium does not agree with this result.

The present study meet objectives of study and find some novel combinations of plant growth regulators for lentil micropropagation and rooting. There is need to carryout further experiments to understand physiological and molecular events affecting shoot and root induction in lentil.

\section{References}

Aasim M, Ozcan SF, Khawar KM andOzcan S 2012. Comparative studies on the competence of axillary shoot regeneration on unsliced and longitudinally sliced cotyledon nodes of Vigna unguiculata. Turk. J. Bot. 36: 281-287.

Aasim M, Khawar KM and Ozcan S 2008. In vitro micropropagation from shoot meristems of Turkish Cowpea (Vigna unguiculata L.) cv. Akkiz. Bangladesh J. Bot. 37(2): 149-154.

Aasim M, Khawar KM and Ozcan S 2009. In vitro micropropagation from plumular apices of Turkish cowpea (Vigna unguiculata L.) cultivar Akkiz. Sci Hortic-Amsterdam 122(3): 468-471.

Ahmad M, Fautrier AG, McNeil DL, Hill GD and Buritt DJ 1996/1997. In vitro propagation of Lens species and their interspecific hybrids. Plant. Cell. Tiss. Org. Cult. 47: 169-176.

Bajaj YPS and Dhanju MS 1979. Regeneration of plants from apical meristem tips of some legumes. Curr. Sci. 48: 906-907.

Basalma D, Uranbey S, Mirici S and Kolsarici O 2008. TDZ x IBA induced shoot regeneration from cotyledonary leaves and in vitro multiplication in safflower (Carthamus tinctorius L.). Afr. J. B1otecnol. 7(8): 960-966.

Christianson ML and Warnick DA 1985. Temporal requirement for phytohormone balance in the control of organogenesis In vitro. Dev. Biol. 112: 494-497.

Fratini R and Ruiz ML 2002. Comparative study of different cytokinins in the induction of morphogenesis in lentil (Lens culinaris Medik.). In vitro cellular and Dev. Biol. Plant. 38: 46-51.

Ghanem SA, Moursy HA, Reda AA and El-Bahr MK 1989. Effect of some growth regulators on the growth of Lens culinaris Medik., cultured in vitro. African J. Agr. Sci. 16: 155-161.

Khawar KM and, Özcan S 2002. High frequency shoot regeneration from cotyledonary node explants of different lentil (Lens culinaris Medik) genotypes and in vitro micrografting. Biotechnol. Biotech. Eq. 16: $12-17$.

Khawar KM, Sancak C, Uranbey S and Ozcan S 2004. Effect of thidiazuron on shoot regeneration from different explants of Lentil (Lens culinaris Medik.) via organogenesis. Turk. J. Bot. 28: 421-426.

Khawar KM, Sarihan E, Sevimay C, Çöçü S, Parmaksız I, Uranbey S, Ipek, A, Kaya MD, Sancak Cand Özcan S 2005. Adventitious shoot regeneration and micropropagation of Plantago lanceolata L. Period. Biol. 107(1): 113-116.

Murashige T and Skoog, F. 1962. A revised medium for rapid growth and bio-assays with tobacco tissue cultures. Physiol. Plant. 15(3): 473-497.

Malik K.Aand Saxena, P.K. 1992a. In vitro regeneration of plants: A novel approach. Naturwissenschaften 79: $136-137$.

Malik KA and Saxena PK 1992b. Thidiazuron induces high frequency shoot regeneration in intact seedlings of pea (Pisum sativum), chickpea (Cicer arietinum) and lentil (Lens culinaris). Aust. J. Plant. Physiol. 19: $731-740$. 
Mallick MA and Rashid A 1989. Induction of multiple shoots from cotyledonary node of grain legumes, pea and lentil. Biol. Plant 31: 230-232.

McDaniel CN 1984. Competence, determination and induction in plant development. In: Pattern formation: A Primer in Developmental Biology (Malacinski G (Ed)., pp. 393-342.MacMillan, New York.

Özgen M, Özcan S, Sevimay CS, Sancak C and Y1ldı, M 1998. High frequency adventitious shoot regeneration in Sainfoin. Plant Cell. Tiss. Org. 52: 205-208.

Polanco MC 2001. Factors that affect plant regeneration from in vitro culture of immature seeds in four lentil genotypes. Plant Cell. Tiss. Org. Cult. 66: 133-139.

Polanco MC and Ruiz ML 1997. Effect of benzylaminopurine on in vitro and in vivo root development in lentil (Lens culinaris Medik.). Plant Cell. Rep. 17: 22-26.

Polanco MC, Peláez MI and Ruiz ML 1988. Factors affecting callus and shoot formation from in vitro cultures of Lens culinaris Medik. Plant Cell. Tiss. Org. Cult. 15: 175-182.

Saxena PK and King J 1987. Morphogenesis in lentil: plant regeneration from callus cultures of Lens culinaris Medik. via somatic embryogenesis. Plant Sci. 52: 223-227.

Sevimay CS, Khawar KM and Yuzbasioglu E 2005. Adventitious shoot regeneration from different explants of wild lentil (Lens culinaris subsp. Orientalis). Biotechnol. \& Biotechnol. Eq. 19(2): 46-49.

Snedecor GW and Cochran WG 1967. Statistical Methods. The Iowa State University Press, Iowa, USA.

Williams DJ, Boyd L and McHughen A 1986. Plant regeneration of Lens culinaris Medik (lentil) in vitro. Plant Cell. Tiss. Org. Cult. 7: 149-153.

Ye G, McNeil DL, Conner AJ and Hill GD 2000. Improved protocol for the multiplication of lentil hybrids without genetic change by culturing single node explants. J. Breed. and Gene 32(1):13-21.

Ye G, McNeil DL, Conner AJ and Hill GD 2002. Multiple shoot formation from mature seeds in lentils (Lens culinaris). New. Zeal. J. Crop Hort. 30: 1-8.

(Manuscript received on 31 December, 2013; revised on 24 April, 2014) 